\title{
IKK inhibition by BMS-345541 suppresses breast tumorigenesis and metastases by targeting GD2+ cancer stem cells
}

\author{
Venkata Lokesh Battula1,2, Khoa Nguyen ${ }^{1}$, Jeff Sun ${ }^{1}$, Mary Kathryn Pitner ${ }^{2}$, Bin \\ Yuan $^{1}$, Chandra Bartholomeusz ${ }^{2}$, Numsen Hail ${ }^{1}$ and Michael Andreeff ${ }^{1}$ \\ ${ }^{1}$ Department of Leukemia, Section of Molecular Hematology and Therapy, University of Texas MD Anderson Cancer Center, \\ Houston, TX, USA \\ ${ }^{2}$ Department of Breast Medical Oncology, University of Texas MD Anderson Cancer Center, Houston, TX, USA \\ Correspondence to: Venkata Lokesh Battula, email: vbattula@mdanderson.org \\ Michael Andreeff, email: mandreef@mdanderson.org \\ Keywords: breast cancer, cancer stem cells, GD2, GD3 synthase, NFKB \\ Received: October 13, $2016 \quad$ Accepted: March 01, $2017 \quad$ Published: March 16, 2017
}

Copyright: Battula et al. This is an open-access article distributed under the terms of the Creative Commons Attribution License (CC-BY), which permits unrestricted use, distribution, and reproduction in any medium, provided the original author and source are credited.

\section{ABSTRACT}

We have identified that the ganglioside GD2 is a marker for breast cancer stem cells (BCSCs), and that targeting the enzyme GD3 synthase (GD3S, which regulates GD2 biosynthesis) reduces breast tumorigenesis. The pathways regulating GD2 expression, and their anomalous functions in BCSC, are unclear. Proteomic analysis of GD2+ and GD2- cells from breast cancer cell lines revealed the activation of NFKB signaling in $\mathrm{GD2}^{+}$cells. Dose- and time-dependent suppression of NFKB signaling by the small molecule inhibitor BMS-345541 reduced GD2 ${ }^{+}$cells by $>90 \%$. Likewise, BMS-345541 inhibited BCSC GD3S expression, mammosphere formation, and cell migration/invasion in vitro. Breast tumor-bearing mice treated with BMS-345541 showed a statistically significant decrease in tumor volume and exhibited prolonged survival compared to control mice, with a median survival of $78 \mathrm{~d}$ for the BMS-345541treated group vs. $58 \mathrm{~d}$ for the controls. Moreover, in an experimental metastases model, treatment with BMS-345541 reduced the lung metastases by $>\mathbf{5}$-fold. These data suggest that GD2 expression and function, and NFKB signaling, are related, and they control BCSCs tumorigenic characteristics. Thus, the suppression of NFKB signaling by BMS-345541 is a potentially important advance in controlling breast cancer growth and metastases.

\section{INTRODUCTION}

Breast cancer stem cells (BCSCs) are a subpopulation of primary breast tumor cells that are resistant to most conventional chemotherapeutic agents, and hence they can cause secondary primary tumors if they are not eradicated from the body via surgery or radiotherapy $[1,2]$. These cells can also cause tumor metastasis through their ability to dissociate from the primary tumor and invade vicinal tissues and vasculature [3]. Because of their quiescent nature, BCSCs are difficult to target in general [4], and molecular characteristics that are specific for these cells are in desperate need of identification.

Recently, our group identified the ganglioside GD2 as a marker for BCSCs [5]. GD2 is co-expressed on well-established $\mathrm{CD} 44^{\text {high }} \mathrm{CD} 24^{\text {low }}$ cells, and $\mathrm{GD} 2^{+}$cells can form mammospheres in low-adherent conditions, migrate, and invade in vitro. They can also initiate tumors from as few as 10 cells in vivo. We also found that GD3 synthase (GD3S), an enzyme that synthesizes GD3 that is a precursor molecule for GD2, was highly expressed on $\mathrm{GD} 2^{+}$breast cancer cells [5]. Genetic and pharmacologic inhibition of GD3S reduced GD2 expression and inhibited tumor growth in vivo. Inhibition of GD3S expression also reduced lung metastases of breast cancer cells in immunodeficient mice [6].

We also recently reported that the overexpression of the NFKB (p65) super-repressor inhibited GD3S expression in breast cancer cells [6]. NFKB is activated via "canonical" and "non-canonical" pathways. The canonical pathway is triggered by pro-inflammatory cytokines such 
as TNF $\alpha$ and IL-1. The non-canonical NFאB pathway is activated by TNF family cytokines [7, 8], CD40 ligand [7], B-cell activating factor (BAFF/TNFSF13B) [9], and receptor activator of $\mathrm{NF} \kappa \mathrm{B}$ ligand (RANKL/TNFSF11) [10] resulting in the activation of RelB/p52 complexes [9]. NF $\kappa \mathrm{B}$ is a known regulator of many aberrant cellular functions in cancer cells, including cell migration, chemoresistance, and tumor engraftment [11-13] Yamamoto et al., reported that NFאB non-cell autonomously regulated cancer stem cells in basal-like breast cancer, suggesting a major role of this signaling pathway in BCSC function [14].

To date, the signaling pathways regulating GD2 expression and their anomalous functions in BCSC are unclear. In this manuscript, we show that $\mathrm{NF} \kappa \mathrm{B}$ signaling is activated in $\mathrm{GD}^{+} \mathrm{BCSC}$ and that the inhibition of this signaling by the IKK $\alpha / \beta$ inhibitor BMS-345541 suppresses BCSC tumorigenic functions, including metastasis. In addition, we identify BMS-345541 as a potential therapeutic agent to inhibit the spontaneous generation of $\mathrm{GD}^{+} \mathrm{BCSCs}$, which could conceivably inhibit breast cancer growth and metastases.

\section{RESULTS}

\section{Proteomic profiling revealed activation of NFKB signaling in $\mathrm{GD2}^{+}$compared to GD2- cells}

The signaling pathways regulating GD3S and GD2 expression are unclear. To identify potential components of these pathways, GD2 ${ }^{+}$and GD2- cells from MDAMB-231 and SUM159 breast cancer cell lines were sorted using FACS, and the cell lysates were assayed on a Kinexus antibody microarray. A total of 850 different validated proteins, belonging to various signaling pathways, were assayed in each sample. The proteins that were differentially expressed or phosphorylated in the $\mathrm{GD}^{+}$and the GD2- SUM159 (Table 1) and MDA-MB-231 cells (supplementary Table 1) were organized based on their z-scores [15]. Pathway analysis of the differentially expressed and phosphorylated proteins using Ingenuity pathway analysis tool revealed the activation of $\mathrm{NF} \kappa \mathrm{B}$, STAT3, focal adhesion kinase (FAK), p53, platelet-derived growth factor $\beta$ (PDGF $\beta$ ), and p38 MAPK signaling pathways, among others, in the GD2 ${ }^{+}$cells (Supplementary Figure 1).

To validate the antibody array data, we performed CyTOF. MDA-MB-231 cells were stained with antibodies to identify both extra-cellular and intra-cellular targets. CyTOF identified a fraction (i.e., $13 \% \pm 2 \%$ ) of GD2 ${ }^{+}$ cells equivalent to that observed (i.e., $14 \pm 2.5 \%$ ) using conventional flow cytometry (Figure 1). The multiparameter CyTOF data generated from MDA-MB-231 cells were analyzed by SPADE software [16]. Figure 1B shows the tree structures generated by SPADE analysis, revealing that $\mathrm{pPI} 3 \mathrm{~K}$ and $\mathrm{pmTOR}$ were down-regulated in the $\mathrm{GD} 2^{+}$cells. Interestingly, $\mathrm{pNF} \kappa \mathrm{B}$ was up-regulated in $\mathrm{GD} 2^{+}$cells compared with their GD2- counterparts. Next, to investigate if GD2 and GD3S expression was dependent on NFKB signaling, we knocked down IKK $\alpha$ (a crucial factor in mediating canonical and non-canonical $\mathrm{NF} \kappa \mathrm{B}$ signaling), in MDA-MB-231 using shRNA (Figure 2C). mRNA and protein expression analysis validated inhibition of IKK $\alpha$ expression by 70 to $90 \%$ in IKK $\alpha$ knock-down, compared to control, cells (Figure 2C through 2E). Interestingly, GD3S expression was downregulated $\sim 40 \%$ in the IKK $\alpha$ knockdown compared to controls (Figure $2 \mathrm{D}$ and $2 \mathrm{E}$ ). More importantly, flow cytometry analysis revealed $>80 \%$ decrease in the percentage of GD $2^{+}$cells in IKK $\alpha-K D$ cells compared to the control cells (Figure $2 \mathrm{~F}$ and $2 \mathrm{G})$. These data suggest that $\mathrm{NF} \kappa \mathrm{B}$ signaling is activated in $\mathrm{GD} 2^{+}$cells and inhibition of this pathway by IKK $\alpha$ knockdown inhibits GD2 and GD3S expression in breast cancer cells.

\section{NFкB inhibition by BMS-345541 suppresses tumorigenic and metastatic characteristics in BCSCs}

We recently reported that the overexpression of the $\mathrm{NF} \kappa \mathrm{B}$ (p65) super-repressor inhibited GD3S expression in breast cancer cells [6], suggesting that $\mathrm{NF \kappa B}$ signaling could be an important regulator in BCSC tumorigenic functions. To examine this further, we tested several small-molecule NF $\kappa \mathrm{B}$ signaling inhibitors, including JSH23, wedelolactone, and BMS-345541 to determine their effect on BCSC functions. We found that BMS-345541 was very effective. Treatment of MDA-MB-231 cells with this agent inhibited canonical pathway-associated proteins, including pNFאB (p65), as well as non-canonical pathway-associated proteins, including RelB, in a dosedependent manner (Figure 2A).

To test whether BMS-345541 could also inhibit $\mathrm{GD}^{+}$cell growth, MDA-MB-231 and SUM159 cells were treated with BMS-345541 at various concentrations (i.e., $0.625,1.25,2.5$, and $5 \mu \mathrm{M}$ ) or an equal volume of the vehicle PBS (control) for 24, 48, or $72 \mathrm{~h}$. Treatment with BMS-345541 decreased the percentage of GD2 ${ }^{+}$MDAMB-231 cells from $12.5 \% \pm 3 \%$ to $1.5 \% \pm 1 \%$, and it inhibited the absolute number of GD2 ${ }^{+}$cell numbers by $>90 \%$ in a dose- and a time-dependent manner (Figure $2 \mathrm{~B}$ and $2 \mathrm{C}$ ). We have reported that GD2 expression is tightly regulated by GD3S in BCSCs [5]. Therefore, we next tested whether BMS-345541 could inhibit GD3S expression at the transcription level. In MDA-MB-231 cells treated with BMS-345541, GD3S mRNA expression was dramatically inhibited, by $>98 \%$ (Figure 2D), indicating that GD3S expression is highly dependent on active $\mathrm{NF} \kappa \mathrm{B}$ signaling. 
A)
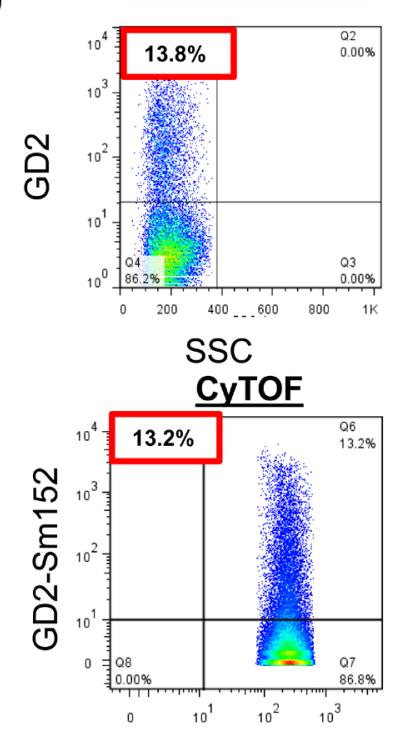

DNA intercalator -Ir191
B)

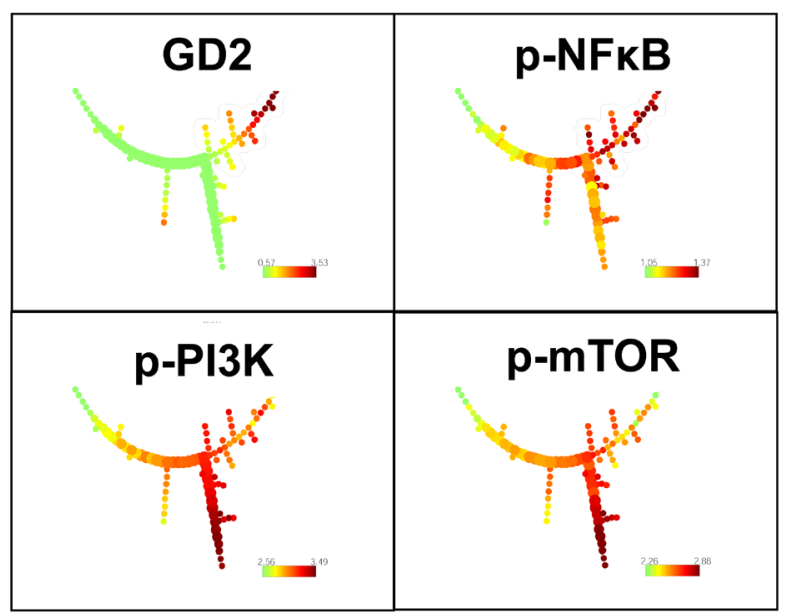

C)

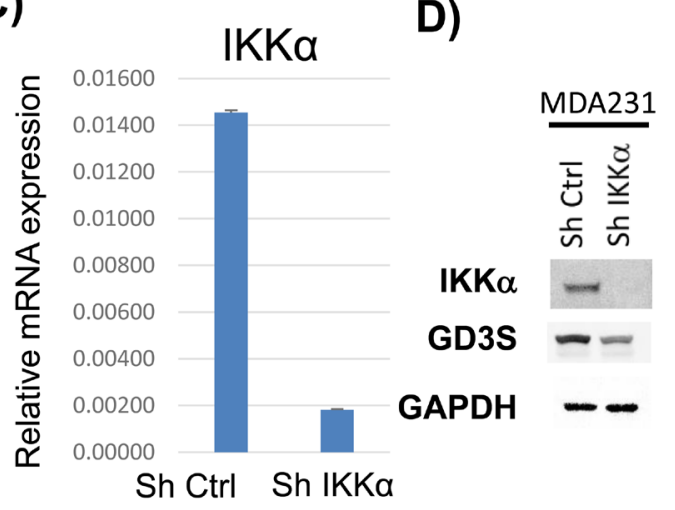

E)

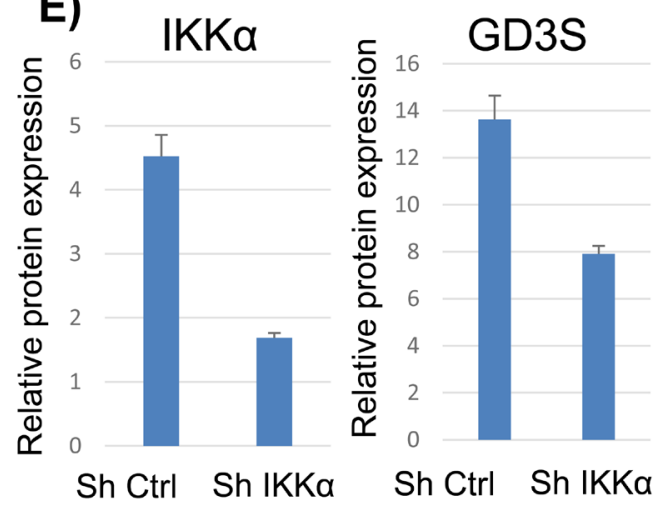

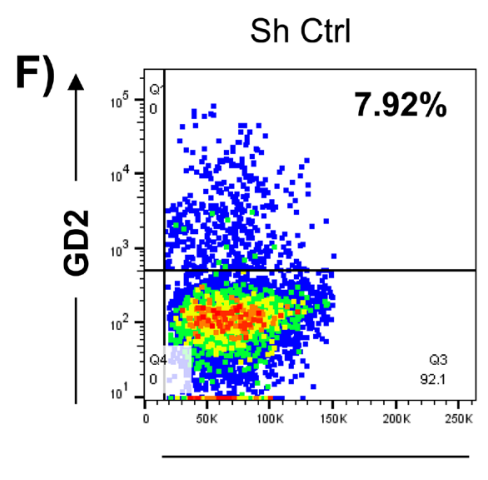

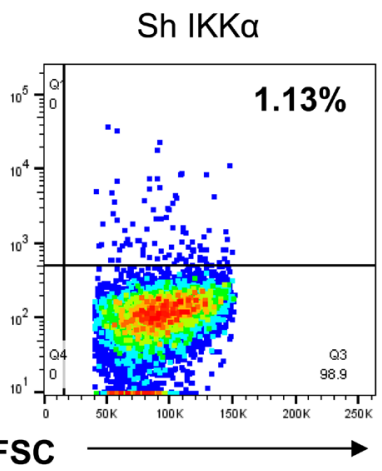

G)

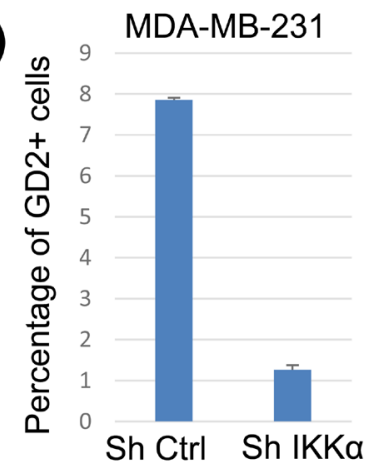

Figure 1: Activation of NFKB signaling in GD2 ${ }^{+}$cells. A. MDA-MB-231 cells were stained with anti-GD2 conjugated with phycoerythrin (fluorochrome) or Sm152 (metal) and analyzed on an LSR II flow cytometer or by CyTOF, respectively. The data were analyzed on FlowJo software. B. MDA-MB-231 cells were incubated with anti-GD2 antibody conjugated with Sm152, anti-pNFkB(p65) conjugated with Sm149, anti-pPI3K(Y607) antibody conjugated with Gd158, and anti-pmTOR(S248) antibody conjugated with Dy164. All the samples were co-stained with and iridium (DNA-intercalator) conjugated with Rh103 for gating. The cells were analyzed on by CyTOF. The data were analyzed using the SPADE complex data analysis tool. A gradient from green (low) to red (high) indicates expression of each marker in different populations in the SPADE tree structure.. C. qRT-PCR analysis of IKK $\alpha$ in control and IKK $\alpha$ knockdown MDAMB-231 cells. D. Western blot analysis to determine IKK $\alpha$ and GD3S protein expression in control and IKK $\alpha$ knockdown MDA-MB-231 cells. E. Bar graph represents quantification of IKK $\alpha$ and GD3S protein expression in control and IKK $\alpha$ knockdown MDA-MB-231 cells. GAPDH served as loading control F. Flow cytometry analysis was performed to measure GD2 expression in control and IKK $\alpha$ knockdown MDA-MB-231 cells. G. Bar graph represents the percentage of GD2 ${ }^{+}$cells in control and IKK $\alpha$ knockdown MDA-MB-231 cells. 
A)

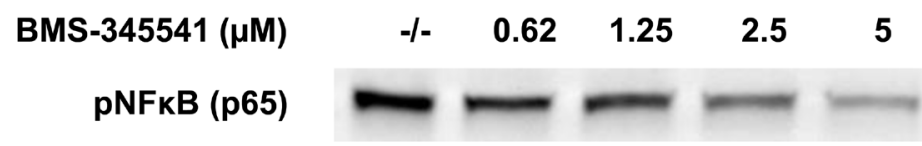

RelB

\section{GAPDH}

B)

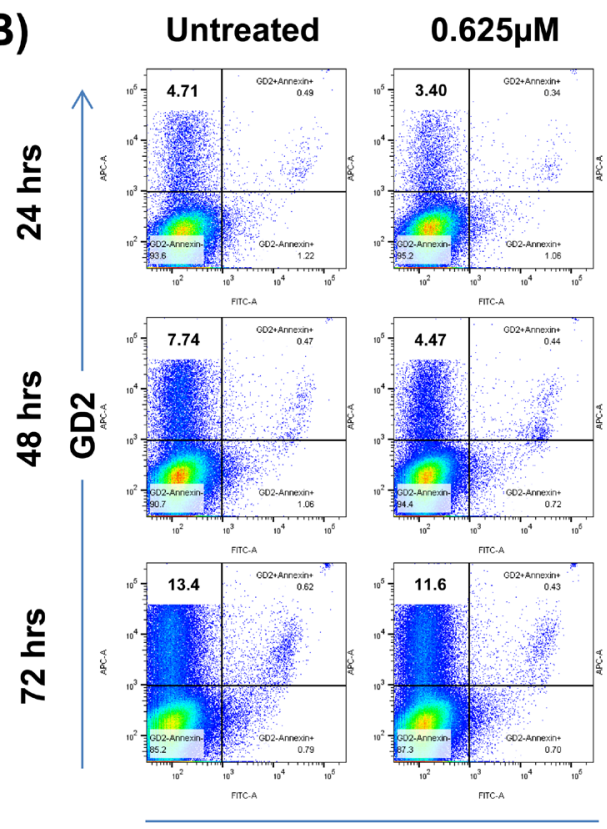

C)

GD2+ cells
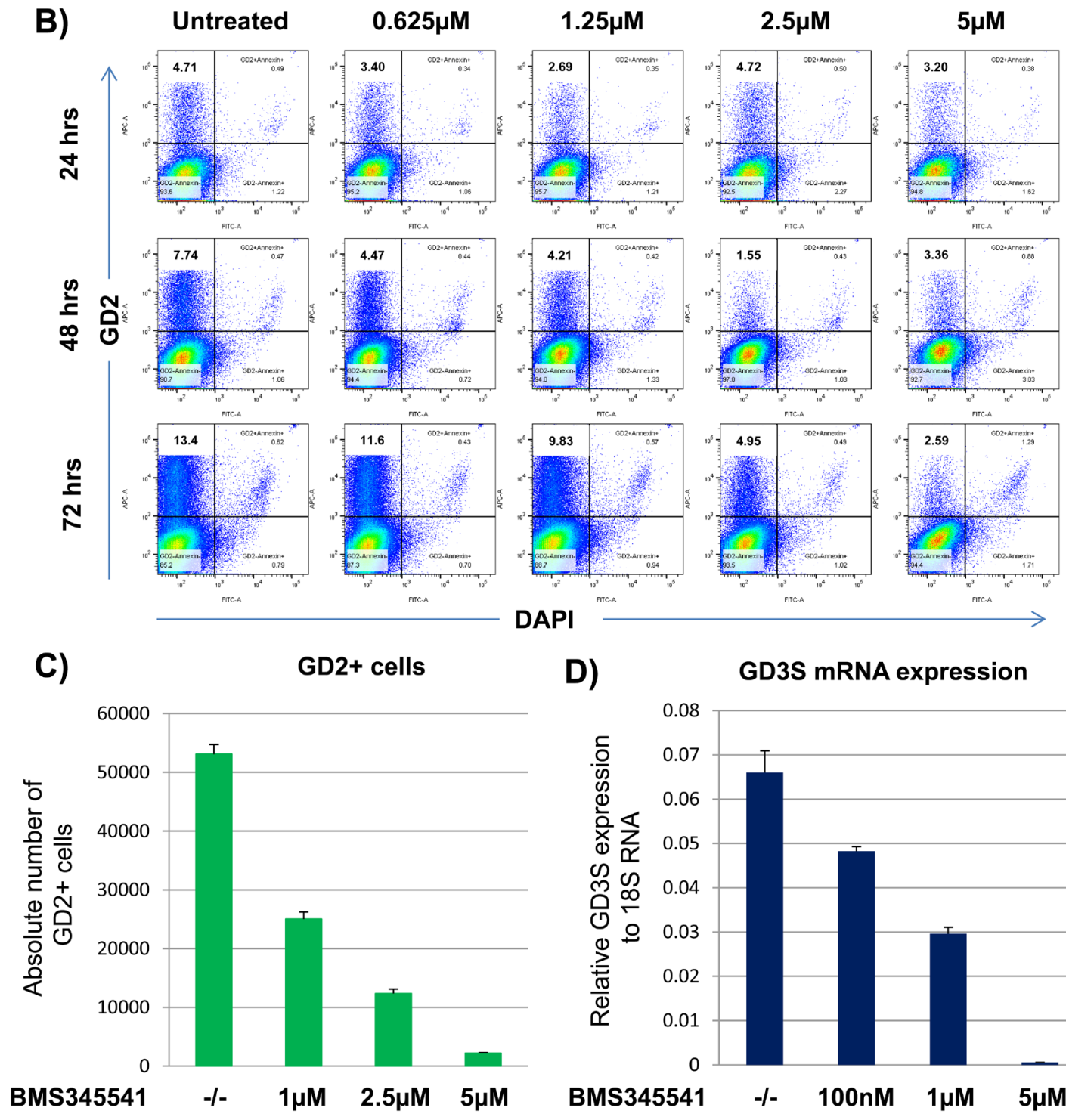

DAPI

D)

GD3S mRNA expression

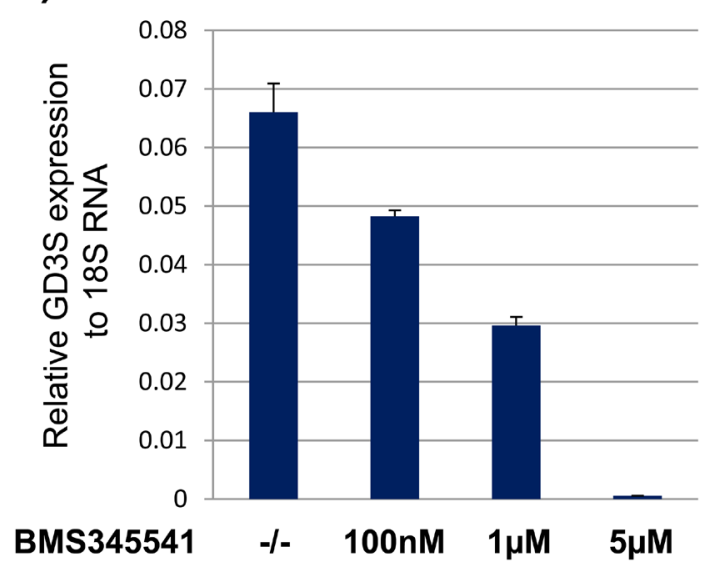

Figure 2: BMS-345541 inhibits GD2 and GD3S expression by inhibiting NFKB signaling in breast cancer cells. A) MDA-MB-231 cells were treated with or without varying concentrations of BMS-345541 for $24 \mathrm{~h}$. For the western blot, the cell lysates were run on a gel, and the transfer membranes were incubated with anti-pNFkB or anti-RelB antibodies. GAPDH served as a loading control. B. MDA-MB-231 cells were treated with BMS-345541 at concentrations of 1, 2.5, and $5 \mu \mathrm{M}$ for $72 \mathrm{~h}$. The cells were then stained with anti-GD2 antibody conjugated with allophycocyanin and analyzed on an LSR II flow cytometer. The cells were also stained with DAPI to exclude dead cells. C. The bar graph represents the absolute number of GD2 ${ }^{+}$cells from the experiment in Figure $2 \mathrm{~A}$. The assay was performed using TruCount absolute counting beads. D. GD3S mRNA expression analysis by quantitative RT-PCR. MDA-MB-231 cells were treated with BMS-345541 at concentrations of $0.1,1$, or $5 \mu \mathrm{M}$ for $24 \mathrm{~h}$. Relative GD3S mRNA expression levels were analyzed by TaqMan quantitative RT-PCR using the 7900HT fast real-time polymerase chain reaction system. 18S RNA served as the equal loading control. 
Table 1: Proteins up- or down-regulated in GD2+ compared with GD2- cells

\begin{tabular}{|c|c|c|c|}
\hline $\begin{array}{l}\text { Target Protein } \\
\text { Name }\end{array}$ & Phospho Site (Human) & Full Target Protein Name & \begin{tabular}{|l|} 
Z-ratio \\
(SUM159-GD2+, \\
GD2-)
\end{tabular} \\
\hline Caveolin 2 & Pan-specific & Caveolin 2 & 3.12 \\
\hline Cyclin E & T395 & Cyclin E1 & 1.89 \\
\hline Csk & Pan-specific & C-terminus of Src tyrosine kinase & 1.89 \\
\hline p38a MAPK & Pan-specific & Mitogen-activated protein-serine kinase $\mathrm{p} 38$ alpha & 1.82 \\
\hline STAT2 & Pan-specific & Signal transducer and activator of transcription 2 & 1.80 \\
\hline S6K & S411 & p70 ribosomal protein-serine $\mathbf{S} 6$ kinase & 1.78 \\
\hline CDK1 (CDC2) & Pan-specific & Cyclin-dependent protein-serine kinase 1 & 1.76 \\
\hline PKR1 & T446 & Double-stranded RNA-dependent protein-serine kinase & 1.73 \\
\hline RelB & S573 & Transcription factor RelB & 1.67 \\
\hline PKG1 & Pan-specific & Protein-serine kinase G1 (cGMP-dependent protein kinase) & 1.67 \\
\hline p25 & Pan-specific & CDK5 regulatory subunit $\mathrm{p} 25$ & 1.51 \\
\hline Pyk2 & Pan-specific & Protein-tyrosine kinase 2 & 1.40 \\
\hline IKKa & T23 & Inhibitor of NF-kappa-B protein-serine kinase alpha (CHUK) & 1.31 \\
\hline Cofilin 1 & Pan-specific & Cofilin 1 & 1.26 \\
\hline YSK1 & Pan-specific & Serine/threonine-protein kinase 25 & 1.25 \\
\hline $\mathrm{PKCh}$ & T655 & Protein-serine kinase $\mathrm{C}$ eta & 1.24 \\
\hline $\mathrm{Cbl}$ & Y700 & Signal transduction protein $\mathrm{CBL}$ & 1.23 \\
\hline MDM2 & S166 & double minute 2 & 1.21 \\
\hline NFKB p 65 & S536 & NF-kappa-B p65 nuclear transcription factor & 1.18 \\
\hline hHR23B & Pan-specific & UV excision repair protein RAD23 homolog B & 1.17 \\
\hline anti-actin & Pan-specific & Actin & 1.15 \\
\hline RSK1 & Pan-specific & Ribosomal S6 protein-serine kinase 1 & 1.12 \\
\hline Smad2 & T200 & Mothers against decapentaplegic homologs 2 & 1.05 \\
\hline $\mathrm{Cdc} 34$ & Pan-specific & Cell division cycle 34 (ubiquitin-conjugating ligase) & 1.05 \\
\hline $\mathrm{PKCe}$ & Pan-specific & Protein-serine kinase $\mathrm{C}$ epsilon & 1.02 \\
\hline Hsp90a/b & Pan-specific & Heat shock $90 \mathrm{kDa}$ protein alpha/beta & 1.01 \\
\hline Hsp60 & Pan-specific & Heat shock $60 \mathrm{kDa}$ protein 1 (chaperonin, CPN60) & -1.02 \\
\hline mMOB1 & Pan-specific & Preimplantation protein 3 & -1.03 \\
\hline Histone $\mathrm{H} 2 \mathrm{~B}$ & S15 & Histone $\mathrm{H} 2 \mathrm{~B}$ & -1.03 \\
\hline JAK2 & Y1007+Y1008 & Janus protein-tyrosine kinase 2 & -1.06 \\
\hline Histone $\mathrm{H} 3$ & S29 & Histone H3.3 & -1.08 \\
\hline JAK3 & Pan-specific & Janus protein-tyrosine kinase 3 & -1.09 \\
\hline c-IAP1 & Pan-specific & $\begin{array}{l}\text { Cellular inhibitor of apoptosis protein } 1 \text { (baculoviral IAP repeat-containing protein 3, apoptosis inhibitor } \\
2 \text { (API2)) }\end{array}$ & -1.10 \\
\hline $\mathrm{Bcl}-\mathrm{xS} / \mathrm{L}$ & Pan-specific & Bcl2-like protein 1 & -1.12 \\
\hline Bcl-xL & Pan-specific & Bcl2-like protein 1 & -1.13 \\
\hline KAP & Pan-specific & Cyclin-dependent kinase associated phosphatase (CDK inhibitor 3, CIP2) & -1.15 \\
\hline p107 & Pan-specific & Retinoblastoma $(\mathrm{Rb})$ protein-related p107 (PRB1) & -1.16 \\
\hline Catenin b1 & Pan-specific & Catenin (cadherin-associated protein) beta 1 & -1.18 \\
\hline EGFR & Y1172 & Epidermal growth factor receptor-tyrosine kinase & -1.19 \\
\hline Hsp90a/b & Pan-specific & Heat shock $90 \mathrm{kDa}$ protein alpha/beta & -1.21 \\
\hline GFAP & S8 & Glial fibrillary acidic protein & -1.22 \\
\hline GRK2 (BARK1) & Pan-specific & G protein-coupled receptor-serine kinase 2 & -1.25 \\
\hline Hsp27 & S15 & Heat shock $27 \mathrm{kDa}$ protein beta 1 (HspB1) & -1.27 \\
\hline Cyclin A & Pan-specific & Cyclin A1 & -1.29 \\
\hline Erk1 + Erk2 & T202 & $\begin{array}{l}\text { Extracellular regulated protein-serine kinase } 1 \text { (p44 MAP kinase)+Extracellular regulated protein-serine } \\
\text { kinase } 2 \text { (p42 MAP kinase) }\end{array}$ & -1.30 \\
\hline
\end{tabular}




\begin{tabular}{|l|l|l|l|}
\hline EGFR & Pan-specific & Epidermal growth factor receptor-tyrosine kinase & -1.31 \\
\hline IkBb & Pan-specific & Inhibitor of NF-kappa-B beta (thyroid receptor interacting protein 9) & -1.47 \\
\hline CDK9 & Pan-specific & Cyclin-dependent protein-serine kinase 9 & -1.49 \\
\hline Fos & Pan-specific & Fos-c FBJ murine osteosarcoma oncoprotein-related transcription factor & -1.81 \\
\hline PP2B/Aa & Pan-specific & Protein-serine phosphatase 2B - catalytic subunit - alpha isoform & -1.83 \\
\hline IkBa & Pan-specific & Inhibitor of NF-kappa-B alpha (MAD3) & -2.27 \\
\hline
\end{tabular}

Protein lysates from SUM159 cells were analyzed on antibody microarrays (Kinexus). Differentially expressed or activated proteins are listed. $Z$ score transformation provides a way of standardizing data across a wide range of experiments and allows the comparison of independent datasets. Data normalized by Z score transformation can be used directly in the calculation of statistically significant changes in gene expression between different samples. Z-ratio given below are obtained using methods described before [15].

To investigate whether BMS-345541 could inhibit the behavior of BCSCs, we treated MDA-MB-231 and SUM159 cells with various concentrations of BMS345541 and tested their ability to endure anchorageindependent growth in soft agar and as mammospheres, and also their ability to undergo migration and invasion in vitro. BMS-345541 treatment inhibited anchorageindependent mammosphere formation in both MDAMB-231 (Figure 3A) and SUM159 cells (Figure 3B) by 4 - to 5 -fold compared with the vehicle control. Soft agar colony assay revealed that BMS-345541 inhibited growth by $>98 \%$ in MDA-MB-231 cells and by $>60 \%$ in SUM159 cells, suggesting that NFKB-mediated signaling is required for $\mathrm{BCSC}$ tumorigenic qualities (Figure 2C and 2D). Interestingly, the migration assay revealed that BMS-345541 treatment inhibited this activity by SUM159 by approximately 10 -fold (Figure 2E). The matrigel assay using trans-well chambers revealed that BMS-345541 treatment triggered a concentration-dependent inhibition in invasion of SUM159 cells by $>95 \%$ in (Figure 2F). These results suggest that BMS-345541 could inhibit $\mathrm{NF} \kappa \mathrm{B}$, which was seemingly coupled to the tumorigenic characteristics of BCSCs.

\section{BMS-345541 inhibits breast tumor growth and metastases in vivo}

To investigate the effect of BMS-345541 on in vivo tumor growth, $1 \times 10^{6} \mathrm{MDA}-\mathrm{MB}-231$ cells expressing GFP and firefly luciferase were implanted in mammary fat pads of NSG mice $(n=14)$. Upon palpable tumor formation (in roughly $2 \mathrm{wk}$ ), the mice were divided into two groups (n $=7$ per group) and treated with PBS or $25 \mathrm{mg} / \mathrm{kg}$ BMS345541 for $3 \mathrm{~d}$ per week for $4 \mathrm{wk}$ via intra-peritoneal (IP) injections. Tumor growth was measured on a weekly basis by bioluminescence imaging (Figure 4A). We found that BMS-345541 treatment reduced tumor growth 2- to 3-fold compared to the control (Figure 4B). In addition, BMS345541 treatment increased median survival of the mice by $>2$ wk compared with the control (Figure 4C, $78 \mathrm{~d}$ for the BMS-345541-treated group vs. $58 \mathrm{~d}$ for the controltreated group; $P<0.002$ ), suggesting that the inhibition of
NFkB by BMS-345541 could inhibit breast tumor growth in vivo presumably by blocking BCSC function.

To investigate whether BMS-345541 inhibits breast cancer metastases, we used an experimental metastasis model and intravenously implanted MDA-MB-231 cells expressing GFP and firefly luciferase in NSG mice $(n=$ 10). One d after implantation, bioluminescence imaging was performed to ensure that all the mice had similar engraftment. Three $\mathrm{d}$ after implantation, the mice were divided into two groups and started on treatment with PBS or BMS-345541 (25 mg/kg) for $3 \mathrm{~d}$ per wk for $4 \mathrm{wk}$ via intravenous injections. Tumor metastases were measured weekly by bioluminescence imaging. We found that BMS345541 treated mice showed a reduction of reduced total bio-luminescence flux of 2- to 3-fold compared to the controls (Figure 5A). Immunohistochemical analysis by hematoxylin-eosin staining of lung tissues revealed that the BMS-345541-treated group had 3- to 4-fold fewer metastases than the PBS-treated group (Figure 5B). In addition, the size of the metastases was also significantly smaller for the mice treated with BMS-345541 (Figure 5C), indicating that BMS-345541 inhibits GD2 ${ }^{+}$BCSC function and thereby inhibits breast cancer metastases.

\section{DISCUSSION}

We found that inhibition of $\mathrm{NF} \kappa \mathrm{B}$ signaling using the IKK blocker BMS-345541 suppressed GD2 ${ }^{+}$cell number apparently by inhibiting GD3S expression. In addition, BMS-345541 inhibited the tumorigenic function of BCSCs in vitro, and also inhibited in vivo tumor growth and metastases in immunodeficient mice implanted with BCSCs, suggesting a critical role of NFKB signaling in BCSC function.

We have previously reported that the ganglioside GD2 identifies BCSCs and that GD3S regulates GD2 expression in these cells [5]. In addition, treatment with the anti-inflammatory and anti-cancer drug triptolide dramatically inhibited GD2 ${ }^{+}$cells by inhibiting GD3S in MDA-MB-231 and SUM159 cells [5, 6], but the mechanism of action was not known. Triptolide has been reported to inhibit NFKB signaling in T-lymphocytes [17]. Previous studies also report the regulation of breast cancer 
A)

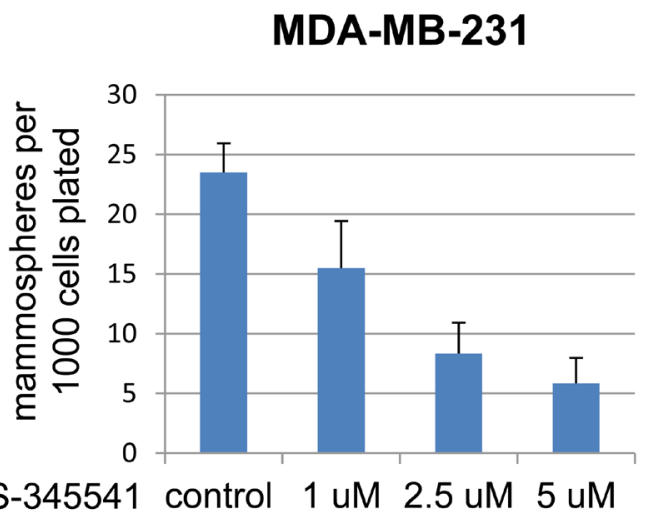
$(\mu \mathrm{M})$

\section{Mammosphere formation}

B)

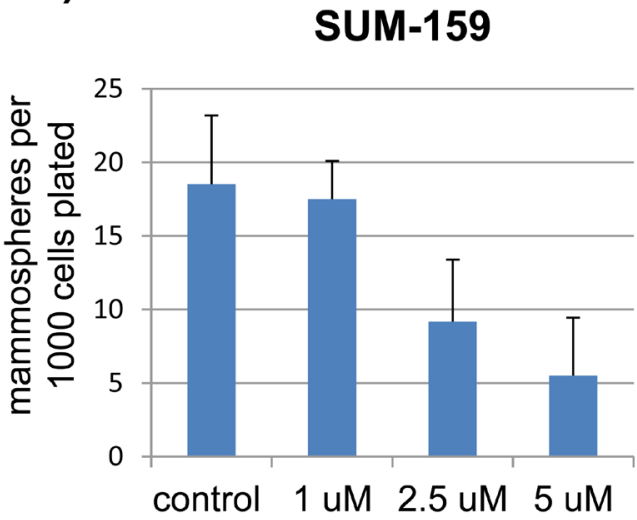

in-vitro tumorigenesis

C)

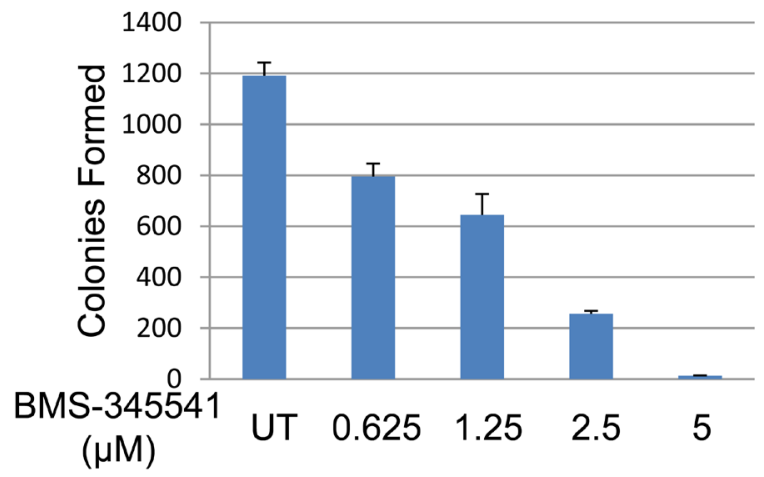

E)

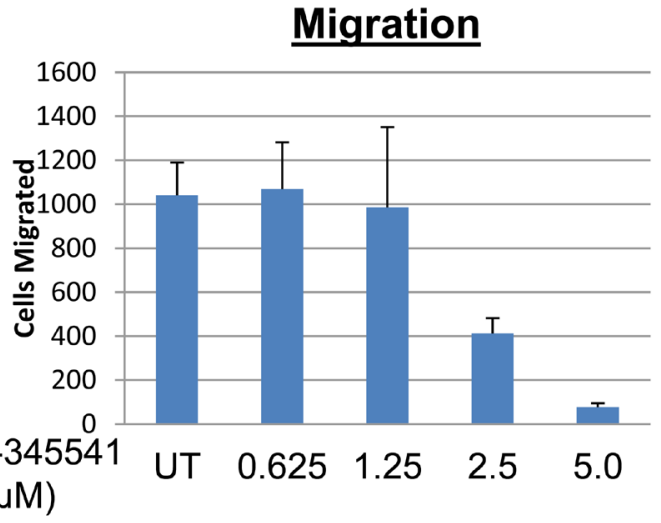

D)

SUM-159

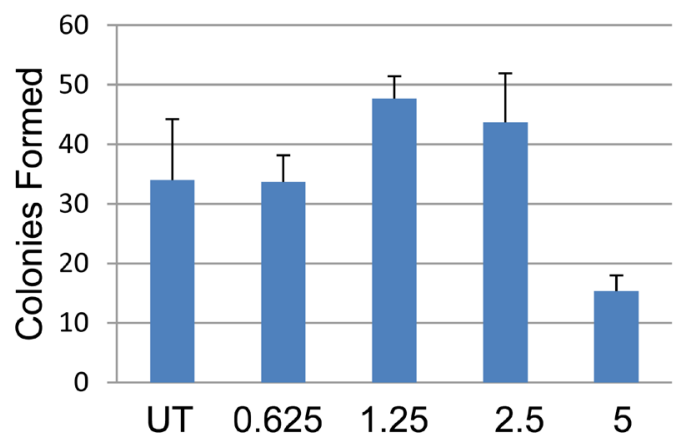

F)

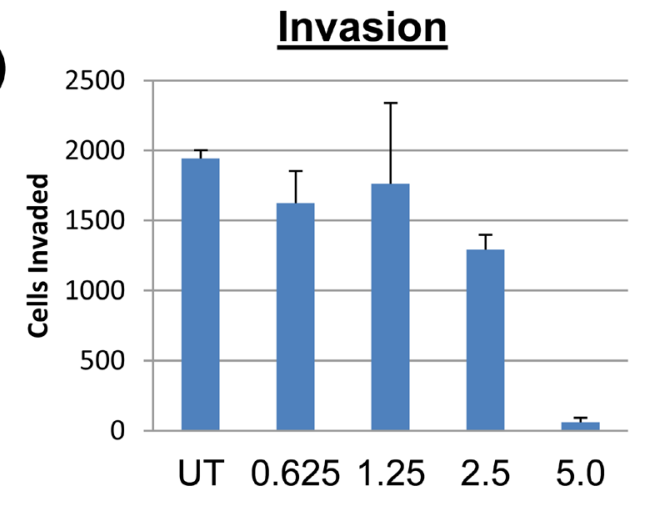

Figure 3: BMS-345541 inhibits function of BCSCs. A. The bar graphs represent the number of mammospheres formed per 5000 MDA-MB-231 (A) or SUM159 B. cells seeded in low-adherent conditions with varying concentrations of BMS-345541 for 2 wk. C. and D. MDA-MB-231 (C) or SUM159 (D) cells were plated into soft agar with varying concentrations of BMS-345541. After 3 weeks of incubation, colonies were fixed with MTT and then counted using an automated colony counter. E. SUM159 cells were plated into transwell migration plates with varying concentrations of BMS-345541. After $6 \mathrm{~h}$, the membrane was fixed and stained, and then cells were counted. F. SUM159 cells were plated into trans-well invasion plates with matrigel; the media contained varying concentrations of BMS345541. After $24 \mathrm{~h}$, the membrane and Matrigel were removed, and the cells were counted. 


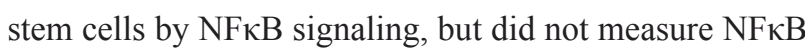
activation exclusively in BCSCs $[14,18]$. In this report, we show that NFאB signaling is activated in $\mathrm{GD}^{+}$, but not in GD2-, breast cancer cells. In addition, we identify BMS345541 as potential tool for modulating GD3S and GD2 by interrupting NFאB signaling.

Activation of $\mathrm{NF} \kappa \mathrm{B}$ signaling in breast cancer has been reported by several investigators [11-13]. Singh et al. first showed NFKB activation in estrogen receptor- negative and Her2 ${ }^{+}$breast tumors and suggested NFאB as a therapeutic target [12]. Cogswell et al. reported selective activation of the $\mathrm{NF \kappa B}$ subunit $\mathrm{NF \kappa B} 2 / \mathrm{p} 52$ in human breast cancer [13]. In addition, our group previously reported that over-expression of the $\mathrm{I} \kappa \mathrm{B}$ super-repressor inhibited GD3S expression in MDA-MB-231 and human mammary epithelial cells expressing Ras oncogene (HMLER). Kang et al. first identified the GD3S promoter sequence (-1146 to -646$)$ in Jurkat T-cells and reported
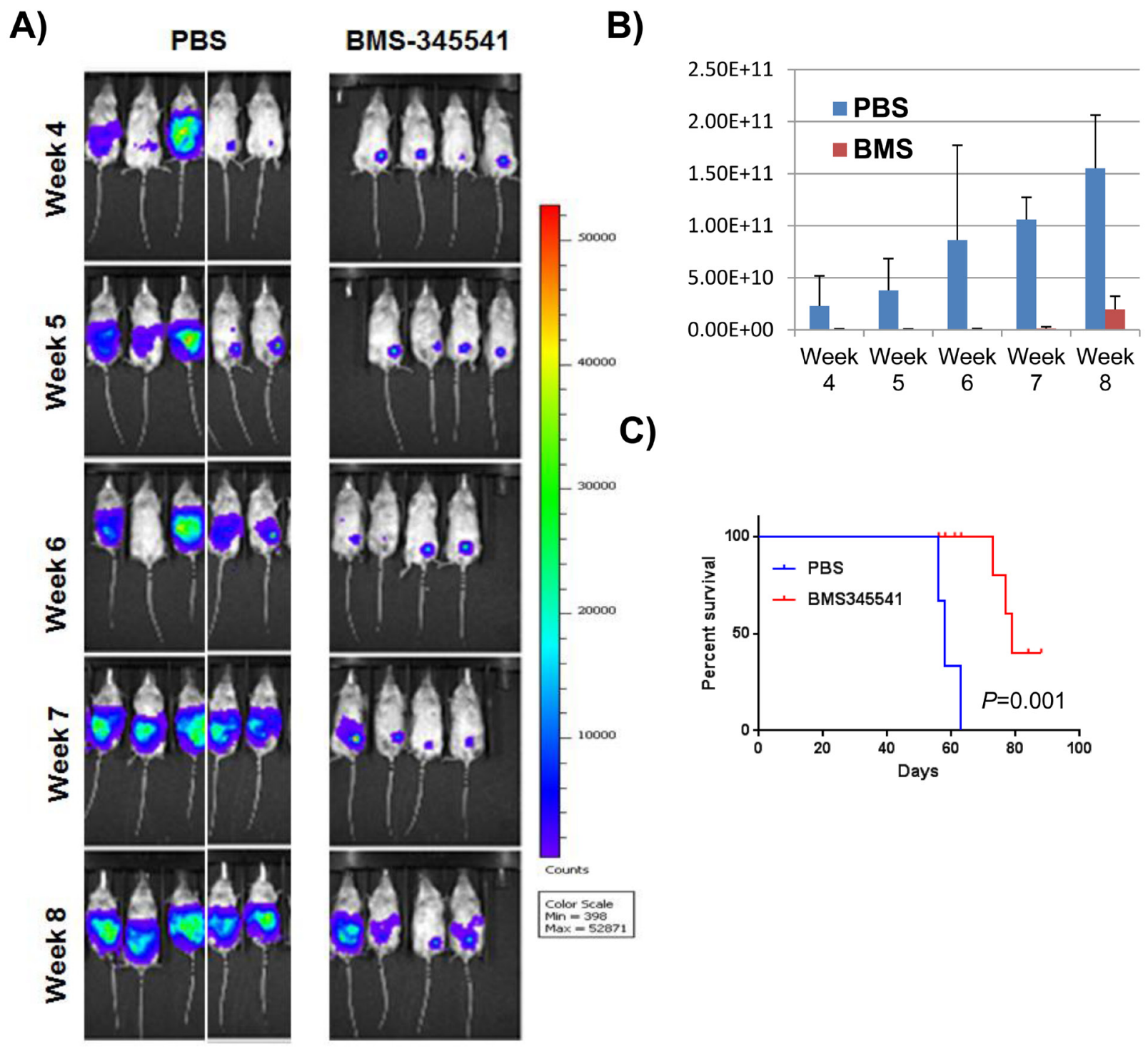

C)

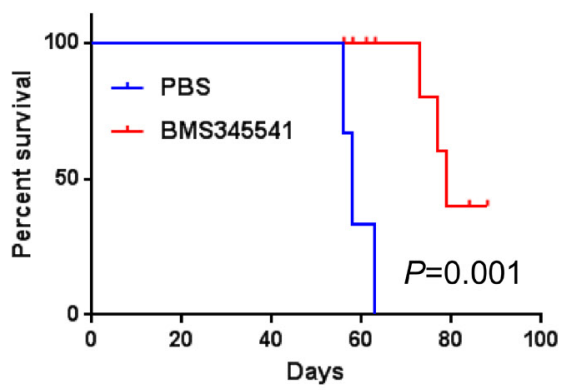

Figure 4: BMS-345541 reduces the rate of tumor growth and increases survival in tumor-bearing mice. A. GFP/ luciferase-expressing MDA-MB-231 cells were implanted into the mammary fat pads of mice $(n=14)$, who were then split into two treatment groups (Seven mice per group); one group was treated with BMS-345541 (25 mg/kg for three treatments per wk for 4 wk), while the other group was treated with control. The images show the luciferase activity in the mice over time. B. The bar graph represents the luminescence levels in the two groups of tumor-bearing mice. The $y$-axis represents the number of photons emitted. C. Survival analysis: Ten mice received MDA-MB-231 cells $\left(1 \times 10^{6}\right.$ cells per mouse $)$ in the mammary fat pads. One group was treated with BMS-345541, while the other group was treated with PBS as a control (three injections per week for 1 week). The survival curves were generated using Prism software (GraphPad Software, San Diego, CA). 
A)

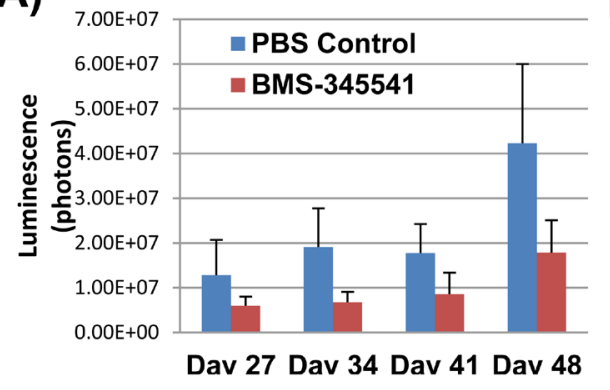

C)

PBS

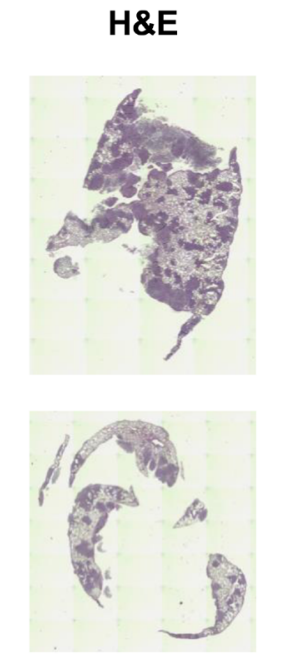

D)

BMS 345541

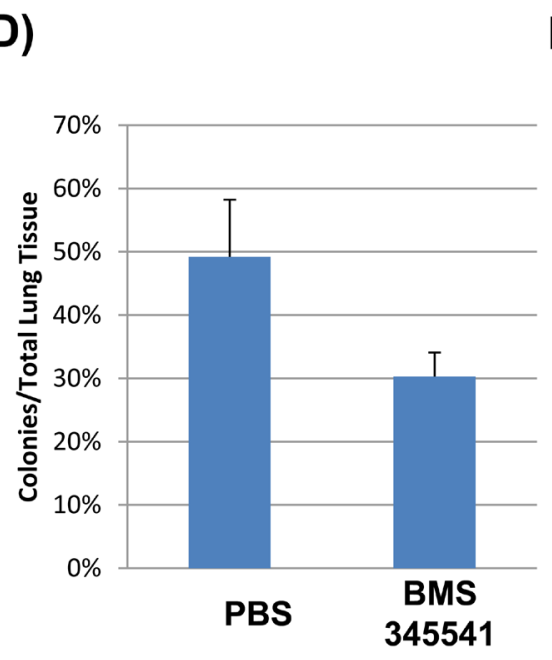

B)

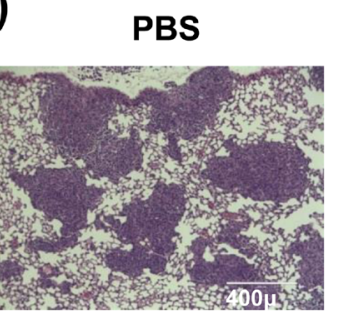

\section{BMS345541}

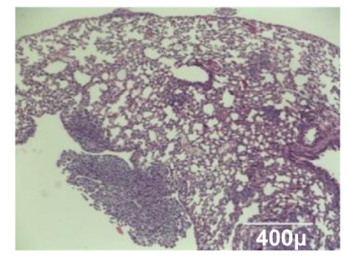

\section{Metastasis Quantification}

Tissue Separation
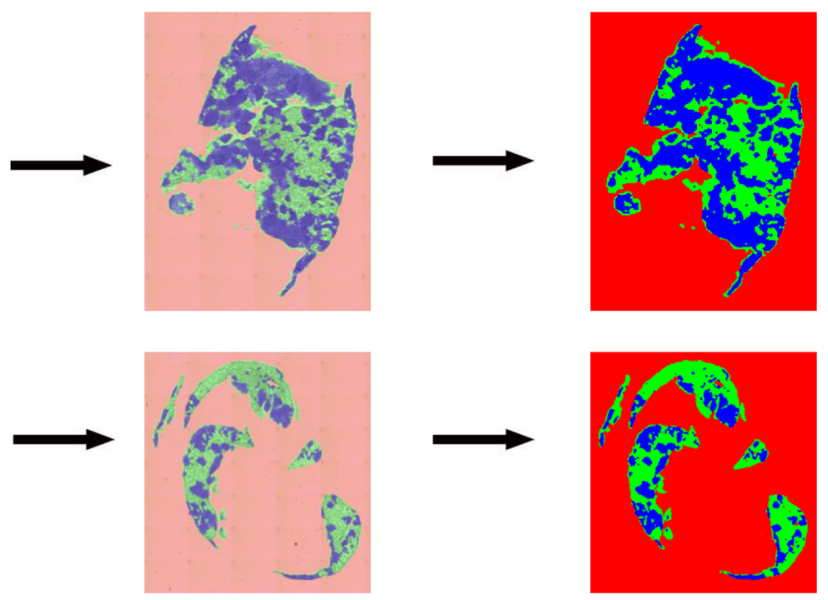

E)

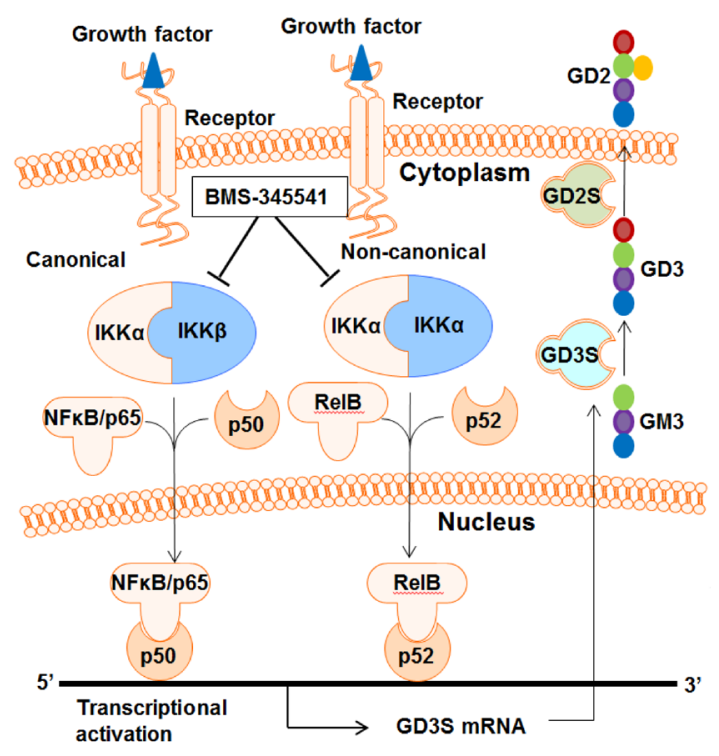

Figure 5: BMS-345541 inhibits cancer metastasis in in vivo settings. A. GFP/luciferase-expressing MDA-MB-231 cells were injected into the tail veins of NSG mice $(n=10)$ in an experimental metastatic model. The mice were then split into two treatment groups; one group (5 mice per group) was treated with BMS-345541, while the other group was treated with PBS. The bar graph represents the luciferase activity of the groups. B. $\mathrm{H}$ and $\mathrm{E}$ staining of lung tissues derived from mice in experiment described in Figure $5 \mathrm{~A}$. The sections are derived from mice on d 34 after tumor implantation. C. and D. To quantitate the amount of metastasis in each group, lungs derived from treated and untreated groups on d 34 were stained with hematoxylin and eosin, and the sections were scanned using EVOS-FL auto microscope and the metastasis was quantitated using inForm software (PerkinElmer). E. The image illustrates the mechanism of action for BMS-345541, an IKK inhibitor. Through inhibition of IKK activity, IкB fails to get phosphorylated, leading to the inhibition of NFkB translocation across the nuclear membrane and inhibition of GD3S and GD2 expression. 
several transcription factors, including cETS1, CREB, AP-1, and NFאB binding sites, in the GD3S promoter sequence [19]. Deletion of NFאB binding sites inhibited Fas-induced GD3S expression, suggesting that GD3S and GD2 expression may depend on NFאB signaling. Reports from Bobowski et al. that estradiol inhibits GD3S expression in breast cancer cells by preventing NF $\kappa B$ to the GD3S promoter [20] further strengthens our current finding that $\mathrm{NF} \kappa \mathrm{B}$ regulates GD3S and GD2 expression.

Recent reports also suggest that the $\mathrm{NF} \kappa \mathrm{B}$ pathway is highly activated in cancer-initiating cells, specifically in BCSCs [18]. Yamamoto et al. reported that NFאB noncell-autonomously regulates cancer stem cell populations in the basal-like breast cancer subtype [14]. The authors found that $\mathrm{NF \kappa B}$ regulates JAG-1 expression and that the NIK-NFאB-JAG1-NOTCH axis regulates the BCSC population. Moreover, Park et al. reported that NFkB signaling promotes osteolytic bone metastasis by inducing osteoclastogenesis via granulocyte macrophage colonystimulating factor [21]. In this report, the authors found that granulocyte macrophage colony-stimulating factor is a key target of NFKB and mediates osteolytic bone metastasis of breast cancer by stimulating osteoclast development. Similarly, our metastases data indicate that BMS-345541 treatment inhibits breast cancer metastases in mice by inhibiting GD2 $2^{+} \mathrm{BCSCs}$, suggesting a critical role of $\mathrm{NF} \kappa \mathrm{B}$ signaling in breast cancer metastasis.

Kendellen et al. reported that both canonical and non-canonical NFאB pathways promote BCSCs. Knockdown of IKK $\alpha$ or IKK $\beta$ inhibited epithelialmesenchymal transition marker expression [22]. We tried several inhibitors, including JSH-23, wedelolactone, and BMS-345541, to inhibit NFKB activity and its downstream targets; only BMS-345541 successfully inhibited GD3S and GD2 expression in a concentration-dependent manner (Figure 2). BMS-345541 targets both IKK $\alpha$ (half maximal inhibitory concentration: $4.2 \mu \mathrm{M}$ ) and IKK $\beta$ (half maximal inhibitory concentration: $0.4 \mu \mathrm{M}$ ) [23], which could be why BMS-345541 was more effective in inhibiting GD3S expression than the other NF $\kappa \mathrm{B}$ inhibitors. A low effective dosage, high specificity for GD2 ${ }^{+} \mathrm{BCSCs}$, inhibition of $\mathrm{BCSC}$ growth in vivo and in vitro make BMS-345541 a potential therapeutic tool for basal-like or triple-negative breast cancer subtypes and suitable for clinical trials.

In conclusion, our data indicate that NF $\mathrm{B}$-mediated signaling is activated in GD2 ${ }^{+}$BCSCs and regulates GD3S expression. BMS-345541 appears to inhibit canonical and non-canonical NFKB signaling by blocking IKK $\alpha$ and $\beta$ in $\mathrm{GD}^{+}$cells inhibiting their ability to form tumors. In combination with conventional chemotherapeutic agents, BMS-345541 could be a potential therapeutic tool in the treatment of metastatic breast cancer.

\section{MATERIALS AND METHODS}

\section{Cell culture}

Human breast cancer cell lines MDA-MB-231 and SUM159 were cultured according to American Type Culture Collection recommendations.

\section{Flow cytometry analysis and fluorescence- activated cell sorting (FACS)}

Single-color staining of MDA-MB-231 and SUM159 cells was performed as described previously [24]. Briefly, $\sim 1 \times 10^{6}$ cells were washed twice with phosphatebuffered saline (PBS) containing 1\% fetal bovine serum (FACS buffer), incubated with anti-GD2 antibody conjugated with allophycocyanin (APC, BioLegend, San Diego, CA) for 30 minutes on ice, and washed in FACS buffer containing 4',6-diamidino-2-phenylindole (DAPI) $(0.5 \mathrm{mg} / \mathrm{ml})$. After being washed, the cells were analyzed with an LSR II flow cytometer (BD; Franklin Lakes, NJ), and the cytometry data were analyzed using FlowJo software. At least $1 \times 10^{4}$ events were measured per sample. FACS was performed to isolate $\mathrm{GD}^{+}$and $\mathrm{GD} 2^{-}$ cells from MDA-MB-231 and SUM159 cells. Cells were stained with anti-GD2 antibody as described above, and sorting was performed on a FACSAria II cell sorter (BD Biosciences, Franklin Lakes, NJ). The absolute number of cells was found using TruCount counting beads (BD Biosciences) per the manufacturer's instructions.

\section{Proteomic analysis}

To investigate signaling pathways activated in BCSCs, GD2 ${ }^{+}$and GD2- MDA-MB-231 and SUM159 cells underwent FACS and were analyzed on an antibody microarray (Kinexus, Vancouver, Canada). Briefly, the cell lysates from GD2 ${ }^{+}$and GD2 cells were labeled with fluorescent probes and applied to glass slides coated with 850 validated antibodies against various total proteins and phosphoproteins per the manufacturer's instructions. After washes, the staining was developed and analyzed on a phosphoimager. The Z-ratio was calculated as described previously [15], and proteins with differential expression or phosphorylation between GD2 ${ }^{+}$and GD2 cells were identified. To understand the functional significance of and signaling pathways associated with GD2 and GD3S expression, we analyzed differentially expressed or activated proteins using Ingenuity Pathway Analysis software (Ingenuity Systems, Redwood City, CA). 


\section{Generation of stable IKKa knockdown breast cancer cells}

We used pLKO lentiviral vectors expressing shRNA against IKKa (Catalog \# RHS3979-201732780; GE Dharmacon, Lafayette, CO) to knockdown IKK $\alpha$ in MDAMB-231 cells. Lentiviral particle expressing IKK $\alpha$ shRNA were generated using packaging vectors as described previously [5]. The viral supernatant was then incubated with MDA-MB-231 cells for $48 \mathrm{~h}$ and the transduced clones were selected by incubating the cells in puromycin (ThermoFisher Scientific), containing cell culture medium at $2 \mu \mathrm{g} / \mathrm{ml}$ concentration.

\section{Western blotting}

Western blotting was performed as described before [25]. Briefly, 1 million cells were plated into $100-\mathrm{mm}-$ wide tissue culture dishes and incubated at $37^{\circ} \mathrm{C}$ and $5 \%$ $\mathrm{CO}_{2}$ for 24 hours to allow for adjustment and adherence. The cells were treated with PBS or BMS-345541 at various concentrations, including $0.0625,1.25,2.5$, and 5 $\mu \mathrm{M}$, for 24 hours. Cells were subjected to lysis at a density of $3 \times 10^{5} / 50 \mu \mathrm{l}$ in protein lysis buffer (G-Biosciences, St. Louis, MO), mixed with $2 \times$ laemmli buffer (BioRad, Hercules, CA) at 1:1 ratio, and supplemented with a protease inhibitor cocktail (Roche Diagnostics, RischRotkreuz, Switzerland). Cell lysates were loaded onto $10 \%$ polyacrylamide gel (Bio-Rad) for electrophoresis, and then the proteins were transferred to Immobilon-FL membranes (EMD Millipore, Billerica, MA). The membranes were incubated with rabbit anti-pNFkB or rabbit anti-RelB (both from Cell Signaling Technology, Danvers, MA) at a 1:500 or 1:1000 dilution and with mouse antiglyceraldehyde 3-phosphate dehydrogenase (GAPDH) antibodies at a $1: 10,000$ dilution overnight at $4{ }^{\circ} \mathrm{C}$. The membranes were then washed and incubated with donkey anti-mouse immunoglobulin $\mathrm{G}$ antibody conjugated with Alexa Fluor 700 and donkey anti-goat antibody conjugated with Alexa Fluor 800 (both from Thermo Fisher Scientific, Waltham, MA). The membranes were washed again and scanned using the Odyssey fluorescence imaging system (LI-COR Biosciences, Lincoln, NE). For analysis of IKK $\alpha$ knockdown cells, the membranes were incubated with anti-IKK $\alpha$ antibody (Catalog\# SC-7219, Santa Cruz Biotechnology) or GD3S (Catalog\# HPA026775, SigmaAldrich) at 1:100 and 1:200 concentrations respectively. GAPDH served as a loading control.

\section{Real-time reverse transcription polymerase chain reaction (RT-PCR)}

A total of $5 \times 10^{5}$ MDA-MB-231 or SUM159

breast cancer cells were incubated with BMS-345541 at concentrations of $0.625,1.25,2.5$, and $5 \mu \mathrm{M}$ or the control for $24 \mathrm{~h}$ at $37^{\circ} \mathrm{C}$ in six-well cell culture dishes. Real-time RT-PCR was performed using TaqMan gene expression assays from Applied Biosystems (Carlsbad, CA) as described previously [26]. The assay for GD3S was $\mathrm{Hs} 00268157$, and the assay for GAPDH was Hs02758991.

\section{Mass cytometry}

To compare activation of cell signaling proteins between $\mathrm{GD}^{+}$and GD2- MDA-MB-231 cells, Timeof-flight mass cytometry (CyTOF), a novel technology combining atomic mass spectrometry and flow cytometry, was performed as described before [27]. Briefly, the cells were fixed in $1.6 \%$ formaldehyde to stop signal transduction and place the cells in stasis. We then incubated the cells with extracellular anti-GD2 antibody (clone 14.G2a; BD Biosciences) conjugated with samarium (isotopic mass: 152). Once extracellular antibody binding was complete, the cells were fixed and permeabilized with $50 \%$ methanol and then were incubated with an intracellular antibody cocktail, which consisted of anti-pNFkB (p65)-Sm149, anti-pPI3K(Y607)-Gd158, and anti-pmTOR(S248)-Dy164. Anti-pPI3K(Y607)-Gd158 and anti-pmTOR(S248)-Dy164 were kindly gifted by Dr. Scott Tanner from the University of Toronto, Canada. After extracellular and intracellular binding, we stained the cells with iridium dye (DNA intercalator-Rh103; Fluidigm) overnight to prepare for CyTOF. PBS with $0.5 \%$ bovine serum albumin was used as a wash and incubation buffer throughout, as it acts as a carrier protein, improving antibody binding and aiding with washing. The cells were analyzed on CyTOF mass cytometry (Fluidigm, South San Francisco, CA). The data were saved in Flow Cytometry Standard 3.0 format and analyzed by spanningtree progression analysis of density-normalized events (SPADE) software, a novel tool for analyzing complex data sets involving multiple parameters [28].

\section{Mammosphere assay}

To investigate the effect of BMS-345541 on the mammosphere formation potential of MDA-MB-231 and SUM159 cells, $1 \times 10^{2}$ or $1 \times 10^{3}$ cells were plated in ultralow attachment 24-well dishes containing mammosphere growth medium (Stemcell Technologies, Vancouver, BC, Canada). The cells were treated with or without BMS345541 at concentrations of $0.625,1.25,2.5$, and $5 \mu \mathrm{M}$. After 10 to $12 \mathrm{~d}$ of culture at $37^{\circ} \mathrm{C}$ in humidified air containing $5 \% \mathrm{CO}_{2}$, the resulting mammospheres were counted using a microscope. 


\section{In vitro tumorigenesis assay}

Two and half milliliters of liquefied solution of $1 \%$ low-melting agarose (Thermo Fisher Scientific, Fair Lawn, NJ) in DMEM medium with 10\% FCS with appropriate drug concentrations (BMS-345541 at 0 , $0.625,1.25,2.5$, and $5 \mu \mathrm{M}$ ) was added to each well in a six-well plate. After the plates were cooled at $4{ }^{\circ} \mathrm{C}$ for 1 hour, an additional $2.5 \mathrm{ml}$ of $0.5 \%$ agarose, complete media solution, the same drug concentrations as above, and 5000 MDA-MB-231 or SUM159 cells were added to each well. The plates were then cooled at $4^{\circ} \mathrm{C}$ for $30 \mathrm{~min}$ and then incubated at $37^{\circ} \mathrm{C}$ and $5 \% \mathrm{CO}_{2}$ for $3 \mathrm{wk}(100 \mu \mathrm{l}$ of media were added weekly to avoid drying of the soft agar gels). The resulting colonies were fixed and stained using $200 \mu \mathrm{l} / \mathrm{well}$ of $1 \mathrm{mg} / \mathrm{ml}$ of 3-(4,5-dimethylthiazol2-yl)-2,5-diphenyltetrazolium bromide (MTT) (Alfa Aesar, Heysham, United Kingdom). The colonies were then counted using an automated colony counter (Oxford Optronix, Abingdon, United Kingdom).

\section{Migration assays}

Migration assays were performed using 24well trans-well chambers as described previously [5]. Membrane inserts with 8- $\mu \mathrm{m}$ pores (Corning, Kennebunk, ME) were used to test the effect of BMS-345541 on cellular migration. The bottom chamber was filled with complete cell culture medium with $10 \%$ FCS. Added to the upper chamber were $3 \times 10^{5}$ MDA-MB-231 or SUM159 cells that were suspended in $200 \mu \mathrm{l}$ of Dulbecco's Modified Eagle Medium containing 1\% FCS and BMS345541 at concentrations of $0.625,1.25,2.5$, and $5 \mu \mathrm{M}$ and the control. The chambers were incubated at $37^{\circ} \mathrm{C}$ and $5 \% \mathrm{CO}_{2}$ for $6 \mathrm{~h}$. The cells that migrated to the other side of the membrane were stained with DAPI (Life Technologies, Carlsbad, CA) and counted under the EVOS-FL automated microscope (Thermo Fisher Scientific).

\section{In vitro matrigel invasion assay}

In vitro migration and invasion assays were performed using 24-well Biocoat Matrigel Invasion Chambers (Corning) containing BD Falcon Cell Culture Inserts with a polyethylene terephthalate membrane (8- $\mu \mathrm{m}$-diameter pore size) treated with Matrigel Matrix (BD Biosciences) as described previously [5]. Briefly, cell suspensions of MDA-MB-231 and SUM159 cells were placed in the Matrigel-coated upper chamber. After incubation at $37^{\circ} \mathrm{C}$ for $24 \mathrm{~h}$ in a $5 \% \mathrm{CO}_{2}$ incubator, the residual cells on the upper surface of the filter were completely removed with cotton swabs. The membranes were then stained, and the cells were counted.

\section{In vivo tumor growth}

All experiments involving animals were approved by and conducted in accordance with the Institutional Animal Care and Use Committee of The University of Texas MD Anderson Cancer Center. GD2 ${ }^{+}$and GD2 MDA-MB-231 cells underwent FACS using a FACSAria II cell sorter (BD). The GD2 ${ }^{+}$and GD2- MDA-MB-231 cells were then transplanted subcutaneously into non-obese diabetic/severe combined immunodeficiency (NSG) mice at concentrations of $10,000,1000$, or 100 cells per site to observe tumor growth. Two injection sites were used per mouse, and five mice were used in each group. The tumors were identified by palpation after $2 \mathrm{wk}$ immediately before the mice were divided into groups. The tumors were treated with BMS-345541 or a control and monitored by bioluminescence imaging. In a similar experiment, MDAMB-231 cells were subcutaneously transplanted $\left(1 \times 10^{6}\right.$ per site) into NOD/SCID mice to observe the cells' tumor initiation potential. In both experiments mice were killed after tumors reached a diameter of $1.5 \mathrm{~cm}$, in accordance with the institutional guidelines.

\section{In Vivo metastasis assay}

All experiments involving animals were approved by and conducted in accordance with the Institutional Animal Care and Use Committee of The University of Texas MD Anderson Cancer Center. 500 thousand MDAMB-231 GFP/Luciferase cells were injected into the tail veins of 20 NSG mice. The mice were then imaged on $\mathrm{d} 1$ and $\mathrm{d} 6$ using the IVIS live bioluminescence imager. After ensuring equal engraftment, the mice were treated twice a week starting on d 7. On d 35, lungs were retrieved, fixed, and stained using hematoxylin and eosin. The slides then imaged using the EVOS (ThermoFisher) imaging system. Whitefield images were sectioned into healthy and metastatic lung colonies using inForm (PerkinElmer) analysis. The sectioned images were converted into simple Red, Green, Blue images. Using Photoshop (Adobe, San Jose, CA), pixels were counted and used to calculate the percentage of metastatic colonies per lung tissue.

\section{Statistical analyses}

Unless otherwise indicated, data are mean \pm standard error of the mean. The statistical significance of tumor growth was determined by a two-way analysis of variance for repeated measures. All other group differences were evaluated by two-tailed unpaired Student t-tests. Survival data were analyzed using Kaplan-Meier log-rank tests. A $P<0.05$ was considered statistically significant. 


\section{Authors' contributions}

Venkata Lokesh Battula conceptualized and designed and performed experiments and wrote the manuscript, Khoa Nguyen performed experiments and wrote manuscript, Jeffrey Sun, Mary Kathryn Pitner, and Bin Yuan performed experiments, Chandra Bartholomeusz performed data analysis, Numsen Hail Jr. edited the manuscript, and Michael Andreeff conceptualized the study and edited the manuscript.

\section{ACKNOWLEDGMENTS}

The University of Texas MD Anderson Cancer Center is supported in part by the National Institutes of Health through the Cancer Center Support Grant P30CA016672, and by the Breast Cancer Research Foundation (BCRF, both to MA). The authors would also like to thank Vivian Ruvolo for technical guidance in viral transductions. Time-of-flight mass cytometry was performed at the Flow Cytometry and Cellular Imaging core facility at MD Anderson Cancer Center.

\section{CONFLICTS OF INTEREST}

The authors declare no financial interests in the findings described in the manuscript.

\section{REFERENCES}

1. Korkaya H, Wicha MS. Breast cancer stem cells: we've got them surrounded. Clinical Cancer Research. 2013; 19:511513.

2. Schatton T, Frank NY, Frank MH. Identification and targeting of cancer stem cells. Bioessays. 2009; 31:10381049.

3. Chaffer CL, Weinberg RA. A perspective on cancer cell metastasis. Science. 2011; 331:1559-1564.

4. Louis CU, Savoldo B, Dotti G, Pule M, Yvon E, Myers GD, Rossig C, Russell HV, Diouf O, Liu E, Liu H, Wu MF, Gee AP, et al. Antitumor activity and long-term fate of chimeric antigen receptor-positive $\mathrm{T}$ cells in patients with neuroblastoma. Blood. 2011; 118:6050-6056.

5. Battula VL, Shi Y, Evans KW, Wang RY, Spaeth EL, Jacamo RO, Guerra R, Sahin AA, Marini FC, Hortobagyi G, Mani SA, Andreeff M. Ganglioside GD2 identifies breast cancer stem cells and promotes tumorigenesis. Journal of Clinical Investigation. 2012; 122:2066-2078.

6. Sarkar TR, Battula VL, Werden SJ, Vijay GV, RamirezPena EQ, Taube JH, Chang JT, Miura N, Porter W, Sphyris N, Andreeff M, Mani SA. GD3 synthase regulates epithelial-mesenchymal transition and metastasis in breast cancer. Oncogene. 2015; 34:2958-2967.

7. Senftleben U, Cao Y, Xiao G, Greten FR, Krahn G, Bonizzi
G, Chen Y, Hu Y, Fong A, Sun SC, Karin M. Activation by IKKalpha of a second, evolutionary conserved, NF-kappa B signaling pathway. Science. 2001; 293:1495-1499.

8. Dejardin E, Droin NM, Delhase M, Haas E, Cao Y, Makris C, Li ZW, Karin M, Ware CF, Green DR. The lymphotoxinbeta receptor induces different patterns of gene expression via two NF-kappaB pathways. Immunity. 2002; 17:525535 .

9. Bonizzi G, Karin M. The two NF-kappaB activation pathways and their role in innate and adaptive immunity. Trends in Immunology. 2004; 25:280-288.

10. Novack DV, Yin L, Hagen-Stapleton A, Schreiber RD, Goeddel DV, Ross FP, Teitelbaum SL. The IkappaB function of NF-kappaB2 p100 controls stimulated osteoclastogenesis. Journal of Experimental Medicine. 2003; 198:771-781.

11. Biswas DK, Shi Q, Baily S, Strickland I, Ghosh S, Pardee $\mathrm{AB}$, Iglehart JD. NF-kappa B activation in human breast cancer specimens and its role in cell proliferation and apoptosis. Proceedings of the National Academy of Sciences U S A. 2004; 101:10137-10142.

12. Singh S, Shi Q, Bailey ST, Palczewski MJ, Pardee AB, Iglehart JD, Biswas DK. Nuclear factor-kappaB activation: a molecular therapeutic target for estrogen receptornegative and epidermal growth factor receptor family receptor-positive human breast cancer. Molecular Cancer Therapeutics. 2007; 6:1973-1982.

13. Cogswell PC, Guttridge DC, Funkhouser WK, Baldwin AS Jr. Selective activation of NF-kappa B subunits in human breast cancer: potential roles for NF-kappa B2/p52 and for Bcl-3. Oncogene. 2000; 19:1123-1131.

14. Yamamoto $M$, Taguchi $Y$, Ito-Kureha $T$, Semba $K$, Yamaguchi N, Inoue J. NF-kappaB non-cell-autonomously regulates cancer stem cell populations in the basal-like breast cancer subtype. Nature Communications. 2013; 4:2299.

15. Cheadle C, Vawter MP, Freed WJ, Becker KG. Analysis of microarray data using $\mathrm{Z}$ score transformation. Journal of Molecular Diagnostics. 2003; 5:73-81.

16. Qiu P, Simonds EF, Bendall SC, Gibbs KD Jr, Bruggner RV, Linderman MD, Sachs K, Nolan GP and Plevritis SK. Extracting a cellular hierarchy from high-dimensional cytometry data with SPADE. Nature Biotechnology. 2011; 29:886-891.

17. Liu H, Liu ZH, Chen ZH, Yang JW, Li LS. Triptolide: a potent inhibitor of NF-kappa B in T-lymphocytes. Acta Pharmacologica Sinica. 2000; 21:782-786.

18. Shostak K and Chariot A. NF-kappaB, stem cells and breast cancer: the links get stronger. Breast Cancer Research. 2011; $13: 214$.

19. Kang NY, Kang SK, Lee YC, Choi HJ, Lee YS, Cho SY, Kim YS, Ko JH, Kim CH. Transcriptional regulation of the human GD3 synthase gene expression in Fas-induced Jurkat T cells: a critical role of transcription factor NF-kappaB in 
regulated expression. Glycobiology. 2006; 16:375-389.

20. Bobowski M, Vincent A, Steenackers A, Colomb F, Van Seuningen I, Julien S, Delannoy P. Estradiol represses the G(D3) synthase gene ST8SIA1 expression in human breast cancer cells by preventing NFkappaB binding to ST8SIA1 promoter. PLoS One. 2013; 8:e62559.

21. Park BK, Zhang H, Zeng Q, Dai J, Keller ET, Giordano T, Gu K, Shah V, Pei L, Zarbo RJ, McCauley L, Shi S, Chen S, et al. NF-kappaB in breast cancer cells promotes osteolytic bone metastasis by inducing osteoclastogenesis via GM-CSF. Nature Medicine. 2007; 13:62-69.

22. Kendellen MF, Bradford JW, Lawrence CL, Clark KS, Baldwin AS. Canonical and non-canonical NF-kappaB signaling promotes breast cancer tumor-initiating cells. Oncogene. 2014; 33:1297-1305.

23. Burke JR, Pattoli MA, Gregor KR, Brassil PJ, MacMaster JF, McIntyre KW, Yang X, Iotzova VS, Clarke W, Strnad J, Qiu Y, Zusi FC. BMS-345541 is a highly selective inhibitor of I kappa B kinase that binds at an allosteric site of the enzyme and blocks NF-kappa B-dependent transcription in mice. Journal of Biological Chemistry. 2003; 278:14501456.

24. Battula VL, Treml S, Bareiss PM, Gieseke F, Roelofs H, de Zwart P, Muller I, Schewe B, Skutella T, Fibbe WE, Kanz L, Buhring HJ. Isolation of functionally distinct mesenchymal stem cell subsets using antibodies against CD56, CD271, and mesenchymal stem cell antigen-1. Haematologica. 2009; 94:173-184.
25. Battula VL, Chen Y, Cabreira Mda G, Ruvolo V, Wang Z, Ma W, Konoplev S, Shpall E, Lyons K, Strunk D, BuesoRamos C, Davis RE, Konopleva M, et al. Connective tissue growth factor regulates adipocyte differentiation of mesenchymal stromal cells and facilitates leukemia bone marrow engraftment. Blood. 2013; 122:357-366.

26. Konopleva M, Contractor R, Tsao T, Samudio I, Ruvolo PP, Kitada S, Deng X, Zhai D, Shi YX, Sneed T, Verhaegen M, Soengas M, Ruvolo VR, et al. Mechanisms of apoptosis sensitivity and resistance to the $\mathrm{BH} 3$ mimetic ABT-737 in acute myeloid leukemia. Cancer Cell. 2006; 10:375-388.

27. Han L, Qiu P, Zeng Z, Jorgensen JL, Mak DH, Burks JK, Schober W, McQueen TJ, Cortes J, Tanner SD, Roboz GJ, Kantarjian HM, Kornblau SM, et al. Single-cell mass cytometry reveals intracellular survival/proliferative signaling in FLT3-ITD-mutated AML stem/progenitor cells. Cytometry A. 2015; 87:346-356.

28. Bendall SC, Simonds EF, Qiu P, Amir el AD, Krutzik PO, Finck R, Bruggner RV, Melamed R, Trejo A, Ornatsky OI, Balderas RS, Plevritis SK, Sachs K, et al. Single-cell mass cytometry of differential immune and drug responses across a human hematopoietic continuum. Science. 2011; 332:687696. 